\title{
On the species status of the root-knot nematode Meloidogyne ulmi Palmisano \& Ambrogioni, 2000 (Nematoda, Meloidogynidae)
}

\author{
Mohammed Ahmed ${ }^{1,2}$, Bart TLH van de Vossenberg', \\ Chris Cornelisse', Gerrit Karssen ${ }^{1,2}$
}

I National Plant Protection Organization, Wageningen Nematode Collection, P.O. Box 9102, 6700 HC Wageningen, The Netherlands 2 Ghent University, Department of Biology, Ledeganckstraat 35, 9000 Ghent, Belgium

Corresponding author: Gerrit Karssen (g.karssen@minlnv.nl)

Academic editor:S. Subbotin | Received 30 September 2013 | Accepted 2 December 2013 | Published 13 December 2013

Citation: Ahmed M, van de Vossenberg BTLH, Cornelisse C, Karssen G (2013) On the species status of the root-knot nematode Meloidogyne ulmi Palmisano \& Ambrogioni, 2000 (Nematoda, Meloidogynidae). ZooKeys 362: 1-27. doi: 10.3897/zookeys.362.6352

\begin{abstract}
The root-knot nematode Meloidogyne ulmi is synonymised with Meloidogyne mali based on morphologi$\mathrm{cal}$ and morphometric similarities, common hosts, as well as biochemical similarities at both protein and DNA levels. M. mali was first described in Japan on Malus prunifolia Borkh.; and M. ulmi in Italy on Ulmus chenmoui W.C. Cheng. Morphological and morphometric studies of their holo- and paratypes revealed important similarities in the major characters as well as some general variability in a few others. Host test also showed that besides the two species being able to parasitize the type hosts of the other, they share some other common hosts. Our study of the esterase and malate dehydrogenase isozyme phenotypes of some $M$. ulmi populations gave a perfectly comparable result to that already known for M. mali. Finally, phylogenetic studies of their SSU and LSU rDNA sequence data revealed that the two are not distinguishable at DNA level. All these put together, leave strong evidences to support the fact that M. ulmi is not a valid species, but a junior synonym of M. mali. Brief discussion on the biology and life cycle of $M$. mali is given. An overview of all known hosts and the possible distribution of M. mali in Europe are also presented.
\end{abstract}

\section{Keywords}

Morphological, morphometrics, esterase, malate dehydrogenase, Japan, Italy, Mierenbos, Malus prunifolia, Ulmus chenmoui, SSU rDNA, LSU rDNA

Copyright Mohammed Ahmed et al. This is an open access article distributed under the terms of the Creative Commons Attribution International License (CC BY 4.0), which permits unrestricted use, distribution, and reproduction in any medium, provided the original author and source are credited. 


\section{Introduction}

The genus Meloidogyne comprises all root-knot nematodes. It contains over 100 described species (Karssen et al. 2013). Its members are without a doubt the most widely distributed of all plant-parasitic nematodes (Sasser 1977). This widespread distribution and their economic importance are primarily the reasons why the genus has been the subject of more research than any other plant-parasitic nematodes, including the cystforming nematodes (Sasser and Carter 1982). Despite the numerous studies about their biology and taxonomy, their identification to the species level still pose a huge challenge to many diagnosticians (Blok and Powers 2009) mostly because of their very small inter-specific morphological variation (Jepson 1987).

In 2000, Palmisano and Ambrogioni described from Italy the root-knot nematode, Meloidogyne ulmi, from Ulmus chenmoui W.C. Cheng on which it was found to induce large galls. For many years, elm remained the only known host of $M$. ulmi. According to the authors, the tree at the type locality was introduced from the Netherlands as part of a breeding programme focussed on resistance to the Dutch elm disease. The Netherlands, like many other countries in Europe and North America, as well as New Zealand, has for years been battling against the notorious Dutch elm disease. It was for this reason that the former Dutch phytopathological laboratory "Willie Commelin Scholten" (WCS), based in Baarn, was mandated with the research on Dutch elm disease. This breeding programme was later on moved to Wageningen at the former institute the Dorschkamp Research Institute for Forestry \& Landscape Planning; and in this programme, elm trees from all over the world were tested. Trial field "Mierenbos", a part of the Dorschkamp Research Institute for Forestry \& Landscape Planning, was used for growing and improving resistant elm cultivars. It was from this trial field that resistant elm seedlings were sent to ten other European countries at the end of the breeding programme, among others, Italy in 1992 (Heybroek 1993).

The first observation of galls on elm trees was already in 1960 at Baarn, and the associating nematode was diagnosed as M. arenaria (Neal, 1889) Chitwood, 1949 by the National Plant Protection Organization (Oostenbrink 1961). Interestingly, about that same period, a Meloidogyne species found parasitizing apple trees in Japan was also inadvertently misidentified as $M$. arenaria, because this nematode species, like the one on elm bore some resemblance to $M$. arenaria perineal patterns (Itoh et al. 1969). This Japanese species would later be described and named M. mali by Itoh et al. (1969). In his comprehensive study on the host range of M. mali, Toida (1979) associated this species with several other plant species belonging to different families, particularly the Rosaceae. Following its description, several studies have also been conducted on its taxonomy, ecology, damage and control (Inagaki 1978), SEM studies of male and second-stage juvenile head morphology, and morphological variability of its different populations (Okamoto et al. 1983). At the trial field "Mierenbos", the first report of galling symptoms on Ulmus trees was in 1979 (Brinkman 1980). Presently, all the Ulmus trees there are infected with Meloidogyne and are showing severe symptoms of root galling (Karssen et al. 2008 and Karssen 2009). 
In 2006, root samples of the dying type host apple containing $M$. mali from the type locality in Japan sent by Dr. Takayuki Mizukubo were received at the Dutch National Plant Protection organization. About the same time, galled root samples of the type host of $M$. ulmi were obtained from Italy. They were propagated and maintained on the Ulmus $\times$ hollandica variety "Wredei". Juveniles isolated from the Japanese apple root samples were used for sequencing and the resulting SSU rRNA sequence was discovered to be almost identical to that of M. ulmi (Holterman et al. 2009). Additionally, isozyme phenotypes of M. ulmi population from the trial field in Wageningen were also compared to that of M. mali from Japan (Karssen unpublished; Sakai and Mizukubo 2009). Those also revealed similar patterns of esterase and malate dehydrogenase to that obtained for M. mali (Sakai and Mizukubo 2009). With these observed similarities, a closer look needed to be taken into these two species. Based on the evidences available to us now, we hypothesize that $M$. ulmi probably entered Europe as M. mali with elm rootstocks imported from Japan. Supporting this is the report that M. mali, in addition to its numerous hosts, can also infect Ulmus davidiana var. japonica (Toida 1979).

The original description of $M$. ulmi differentiates it from $M$. mali on the basis of characters that generally show high intraspecific variations. With the original description being the only paper written about $M$. ulmi, all the known features so far are ones from the original description. On M. mali, however, there have been quite a lot of research on the hosts, life cycle, ecology, detailed morphology, as well as their variations within species (Toida 1979; Inagaki 1978; Okamoto et al. 1983).

The objectives of this current research, therefore, are:

i) to evaluate the morphological similarities between M. mali and M. ulmi.

ii) to search for other host plants, than Ulmus sp. present at the trail field "Mierenbos".

iii) to test $M$. ulmi on selected host plants on which $M$. mali is already known to reproduce.

iv) analyze their biochemical similarities, at the protein and DNA levels.

\section{Materials and methods}

\section{Morphology and morphometrics}

Paratype slides of Meloidogyne ulmi used for morphological and morphometric studies were obtained from Dr. Z.A. Handoo of the USDA Nematode Collection. In addition to these, we obtained $M$. mali specimens on slides taken to the USDA by Dr. Ichinohe during his visit in 1958 as well as additional specimens of males, second-stage juveniles and females stored in formalin that were only recently isolated from root samples sent to USDA by Ichinohe during that same visit. Also, by courtesy of Dr. Hiromichi Sakai and Shigeyuki Sekimoto, paratypes that were deposited at the National Agriculture and Food Research Organization, Agricultural Research Center (Kannondai, Tsukuba, Ibaraki, Japan), the then Central Agricultural Experiment Station were also obtained. All slides were observed 
Table I. The various forms of type specimens of Meloidogyne mali and M. ulmi studied and their sources.

\begin{tabular}{l|l|l|l|l}
\hline \multirow{2}{*}{ Form } & \multicolumn{2}{|l|}{ Meloidogyne mali } & Meloidogyne ulmi \\
\cline { 2 - 5 } & Sex/stage & Source & Sex/stage & Source \\
\hline Holotype & 1 female & Shigeyuki Sekimoto & - & - \\
\hline Allotype* & 1 male & Shigeyuki Sekimoto & - & - \\
\hline Paratype & 17 perineal patterns & Dr. Zafar A. Handoo & 2 PP \& 1 anterior part & Dr. Zafar A. Handoo \\
\hline Paratype & 3 males & Dr. Zafar A. Handoo & 2 males & Dr. Zafar A. Handoo \\
\hline Paratype & 4 juveniles & Dr. Zafar A. Handoo & 3 juveniles & Dr. Zafar A. Handoo \\
\hline Paratype & 1 male & Dr. Hiromichi Sakai & - & - \\
\hline Paratype & 1 juvenile & Dr. Hiromichi Sakai & - & - \\
\hline
\end{tabular}

*Slide marked as allotype, however at present not recognized by the ICZN, i.e. it is a paratype.

Table 2. Plant species included in the host plant test with $M$. ulmi in the greenhouse.

\begin{tabular}{l|l}
\hline \multirow{2}{*}{ Family } & Plant species \\
\hline \multirow{2}{*}{ Brassicaceae } & Brassica oleracea L. var. Gemmifera (cabbage) \\
\cline { 2 - 2 } & Brassica pekinensis (Lour.) Rupr. (celery cabbage) \\
\hline \multirow{2}{*}{ Rosaceae } & Malus pumila "M9" (apple) \\
\cline { 2 - 2 } & Rosa hybrida L. (rose) \\
\hline Fabaceae & Trifolium repens L. (white clover) \\
\hline Solanaceae & Solanum lycopersicum L. (tomato) \\
\hline Ulmaceae & Ulmus glabra Huds. (wych elm) \\
\hline
\end{tabular}

using compound light microscope (DM 2500, LEICA) equipped with differential interference contrast (DIC), and camera (DC 300F, LEICA) for taking images. Comparisons of morphological and morphometric characters were based on the most differential characters, previously used by Karssen (2002).

\section{Host test}

This is a combination of sampling undertaken in 2011 and 2012 at the former trial field "Mierenbos" on several plant species and a subsequent greenhouse experiment involving some important plant species already associated with $M$. mali in previous studies (Itoh et al. 1969; Toida 1979). Host herein is defined as a plant on which the nematode can reproduce, after a successful penetration.

\section{Isozyme analysis}

Esterase and malate dehydrogenase isozymes were analysed for M. ulmi sampled at "Mierenbos", following the method described by Karssen et al. (1995). In summary, young females were isolated from roots into an isotonic $(0.9 \%)$ salt solution. This was followed by a desalting step which involved transfer of the females from the $\mathrm{NaCl}$ solution to a 
reagent-grade water on ice for few minutes. Females were then singly transferred into sample wells containing $0.6 \mu \mathrm{l}$ extraction buffer. With the aid of a small glass rod, the females in the wells were crushed; and the macerated females were then loaded into sample applicators $(0.3 \mu \mathrm{l}$ per well). All twelve wells, with the exception of 6 and 7 , were loaded with our test samples of M. ulmi. M. javanica was used as reference in wells 6 and 7 .

Electrophoresis was run using the PhastSystem (Pharmacia Ltd, Uppsala, Sweden) and the gels were subsequently stained in a Petri dish and placed in an incubator at $37^{\circ} \mathrm{C}$. Staining for non-specific esterase (EST; EC 3.1.1.1) was allowed to stand for 60 minutes whiles that for malate dehydrogenase (MDH; EC 1.1.1.37) stayed for 5 minutes.

Following staining, the gels were rinsed with distilled water and fixed for $5 \mathrm{~min}$ utes in a $10 \%$ acetic acid / $10 \%$ glycerol/ $80 \%$ distilled water solution. Pictures of the gels were taken by placing them on a glass surface illuminated from below.

\section{Molecular analysis}

Already published sequences of both M. mali and M. ulmi (Holterman et al. 2009) together with our own sequence of the latter were included in this analysis.

\section{DNA extraction}

Nucleic acids were isolated from single male or second-stage juveniles of $M$. ulmi populations taken from "Mierenbos" and type populations kept in culture at the Dutch National Plant Protection Organization on an elm tree (Ulmus $\times$ hollandica Mill "Wredei"). Genomic DNAs were isolated from these samples using High Pure PCR Template Preparation Kit (www.roche-applied-science.com, Cat. No. 11796828001, Version 16.0) protocol for isolation of nucleic acids from Mammalian Tissue with slight modification in the first step to suit nematode DNA isolation (150 $\mu \mathrm{l}$ tissue lysis buffer added to $50 \mu \mathrm{l}$ sterile water containing nematodes, minimum protease incubation time of 16 hours and elution volume of $50 \mu \mathrm{l}$ ).

\section{PCR and sequencing}

Amplification of 1000 base pairs (bp) of the large ribosomal subunit (LSU) (28S) was performed using primer set 28-81for (forward) 5'-TTAAGCATATCATTTAGCGGAGGAA-3' and 28-1006rev (reverse) 5'-GTTCGATTAGTCTTTCGCCCCT-3' described by Holterman et al. (2008).

To amplify the nearly full length sequence of the small ribosomal subunit (SSU) (18S), two partially overlapping fragments were generated using three universal primers and one nematode-specific primer (1912R) described by Holterman et al. (2006). The latter's inclusion was to avoid amplification of non-target eukaryotic SSU rDNA, for ex- 
ample from fungal spores attached to the nematode cuticle. The primers $988 \mathrm{~F}$ (forward) (5'-CTCAAAGATTAAGCCATGC-3') and 1912R (reverse) (5'-TTTACGGTCAGAACTAGGG-3') were used to amplify the first fragment. The second fragment was amplified with primers 1813F (foward) (5'-CTGCGTGAGAGGTGAAAT-3') and 2646R (reverse) (5'-GCTACCTTGTTACGACTTTT-3). Each PCR reaction mixture contained Molecular Grade Water (MGW)-DNase RNase free water (Sigma-Aldrich, Saint Louis, USA), 1x PCR buffer (incl. $2.0 \mathrm{mM} \mathrm{MgCl}_{2}$, Roche), dNTPs (0.2 mM each), $0.24 \mu \mathrm{M}$ of each primer, FastStart Taq DNA polymerase $(1 \mathrm{U} / \mu \mathrm{l}$, Roche) and $1 \mu \mathrm{l}$ of the template DNA. The final reaction volume was $25 \mu \mathrm{l}$. PCR was performed in C1000 touch thermal cycler (Bio-Rad) with the following amplification condition: 15 min at $95^{\circ} \mathrm{C} ; 5$ cycles of $30 \mathrm{sec}$ at $94^{\circ} \mathrm{C}, 30$ sec at $45^{\circ} \mathrm{C}$ and 30 sec at $72^{\circ} \mathrm{C} ; 35$ cycles of 30 sec at $94^{\circ} \mathrm{C}, 30 \mathrm{sec}$ at $54^{\circ} \mathrm{C}$ and $30 \mathrm{sec}$ at $72^{\circ} \mathrm{C}$; final extension for $5 \mathrm{~min}$ at $72^{\circ} \mathrm{C}$. To test for amplification and the quality of PCR products, $5 \mu$ l of the PCR products mixed with $1 \mu \mathrm{l}$ 6x Bromophenol Blue Loading solution (Promega, Madison, USA) were subjected to electrophoresis and SYBR safe (Invitrogen, Carlsbad, USA) staining on a $1.5 \%$ agarose gel by standard methods (Sambrook et al. 1989) along with a $1 \mathrm{~kb}$-plus DNA ladder (Invitrogen, Carlsbad, USA) to size fragments. PCR products were imaged under UV light using a GeneGenious gel imaging system (Syngene, Cambridge, United Kingdom).

PCR products were purified after amplification using QIAquick PCR Purification Kit (Qiagen), and the genomic DNA concentration measured using a ND1000 spectrophotometer (NanoDrop). This was followed by a cycle sequencing reaction in a final volume of $20 \mu \mathrm{l}$ (molecular grade water (Sigma-Aldrich, Saint Louis, USA), BigDye Terminator v1.1, 1x sequencing buffer, purified PCR product and $0.5 \mu \mathrm{M}$ templatespecific forward or reverse primers). Cycling reactions were carried out separately for each of forward and reverse primers. The reaction programme was set for $1 \mathrm{~min}$ at $96^{\circ} \mathrm{C}$, $25 \mathrm{x}\left(10 \sec 96^{\circ} \mathrm{C}, 5 \sec 50^{\circ} \mathrm{C}, 2.5 \min 60^{\circ} \mathrm{C}\right), 1 \mathrm{~min} 20^{\circ} \mathrm{C}$. The cycle sequence products were cleaned up using DyeEx 2.0 Spin Kit (Qiagen) and run on a multi-capillary 3500 Genetic Analyzer DNA sequencer (Applied Biosystems, Carlsbad, USA).

\section{Sequence alignment and phylogenetic analyses}

Trace files of D2-D3 expansion segments of $28 \mathrm{~S}$ and 18S-rRNA genes were assembled into contigs and amplification primer sequences trimmed using Geneouis 6.1.6 (Biomatters, New Zealand). Additional trimming was performed when needed, to obtain high quality consensus sequence data. Conflicts in the consensus sequence were assessed visually and corrected where possible. The sequences were aligned with selected sequences of other species from GeneBank using MAFFT alignment (Katoh et al. 2002) within the programme Geneious 6.1.6 (Biomatters New Zealand) for both $28 \mathrm{~S}$ and 18S-rRNA. Alignments were improved manually. Analysis of phylogeny of the sequence data set was performed with Bayesian inference (BI) using MrBayes 3.2.1 (Huelsenback and Ronquist 2001). The optimal model for nucleotide substitution was obtained using JModelTest ver. 2.1.3 (Darriba et al. 2012) with AIC, AICc, BIC and 
DT defaulted in JModelTest. For SSU sequence, analysis of Bayesian inference was performed with a random starting tree and four Markov chains for $1 \times 10^{6}$ under the model TYMef + I. Trees were sampled at interval of 100 generations. Two independent runs were performed for each analysis. The first 100,000 generations were discarded as burn-ins, and the remaining trees combined to generate $50 \%$ majority rule consensus tree which represent posterior probabilities. The same parameter settings were used for LSU phylogenetic analysis, but under the model TYM + G.

\section{Results}

\section{Morphology}

The following are the observations made on selected features considered to be the most differential for species discrimination among members of the genus Meloidogyne (Jepson 1987; Karssen 2002). Table 3 shows a comparison of our observations of the most important characters with the ones mentioned in the original descriptions.

\section{Female}

\section{Perineal pattern}

The general shape of the perineal pattern in both species studied ranged from low rounded to oval. The dorsal arch of M. mali and M. ulmi was mostly low rounded with very few instances where some specimens showed relatively high square patterns. Lateral field was marked by change in direction or breaks in striae resulting in what would appear as weak lateral lines. The double lateral lines mentioned in the description of $M$. mali were not observed in the studied specimens. The interphasmidial distance in both species was about the same as their corresponding vulva slit lengths. As mentioned in the description, the phasmids were distinct but did not appear large when observed at the correct focus. However, attempting to observe them at the same (relatively deeper) focus as the vulva slit makes them look larger and even farther apart than they really are, due to the diagonally sloping phasmid canals.

\section{Stylet}

Same variations in stylet knobs shape as described in M. mali were observed for M. mali paratypes i.e. slightly backwardly sloping to anteriorly concave, with the former being the more frequent. Such variations, however, cannot be mentioned about the M. ulmi paratype since there was only a single anterior part of the female on the slides we obtained. We therefore supplemented it with specimens taken from samples from the "Mierenbos", where the type host originated from. This population showed similar variation as described for M. mali, but not reported in Table 3. Our observation of the shape of the stylet itself was typical of the genus, i.e. straight shaft with a slightly dorsally curved cone. 
Table 3. Observations of the differential characteristics of female, male and second-stage juveniles of Meloidogyne mali and M. ulmi types in comparison with their interpretation in the original description.

\begin{tabular}{|c|c|c|c|c|}
\hline Species & \multicolumn{2}{|c|}{ M. mali } & \multicolumn{2}{|c|}{ M. ulmi } \\
\hline Character & Described & Observed & Described & Observed \\
\hline \multicolumn{5}{|c|}{ Female } \\
\hline Stylet knobs & $\begin{array}{l}\text { Well developed knobs } \\
\text { that tend to slope } \\
\text { backward or forward in } \\
\text { the ratio of } 16 \text { to } 8\end{array}$ & $\begin{array}{c}\text { Rounded to pear- } \\
\text { shaped knobs, set off } \\
\text { and slightly anteriorly } \\
\text { concave to backwardly } \\
\text { sloping }\end{array}$ & $\begin{array}{l}\text { Knobs rounded to } \\
\text { transversely ovoid, } \\
\text { slightly concave } \\
\text { anteriorly }\end{array}$ & $\begin{array}{l}\text { Rounded knobs that } \\
\text { are slightly anteriorly } \\
\text { concave and offset }\end{array}$ \\
\hline $\begin{array}{l}\text { Perineal } \\
\text { pattern }\end{array}$ & $\begin{array}{l}\text { Oval, made up of } \\
\text { smooth striae, finely } \\
\text { spaced, dorsal arch } \\
\text { low and flat. Phasmids } \\
\text { large, lateral field clearly } \\
\text { marked with single or } \\
\text { double incisures }\end{array}$ & $\begin{array}{c}\text { Oval, dorsal arch } \\
\text { low to slightly high, } \\
\text { rounded to square } \\
\text { shaped. } \\
\text { Phasmids distinct. } \\
\text { Lateral field marked } \\
\text { by breaks in the striae } \\
\text { or showing indistinct } \\
\text { lateral lines }\end{array}$ & $\begin{array}{c}\text { Oval, dorsal arch } \\
\text { flattened to medium } \\
\text { high, rounded or } \\
\text { somewhat square, } \\
\text { phasmids conspicuous, } \\
\text { lateral field indistinct } \\
\text { or marked by folds, } \\
\text { sometimes by lateral } \\
\text { lines on one or both } \\
\text { sides }\end{array}$ & $\begin{array}{c}\text { Oval, dorsal arch } \\
\text { low to slightly high, } \\
\text { rounded to square } \\
\text { shaped. } \\
\text { Phasmids distinct. } \\
\text { Lateral field marked } \\
\text { by breaks in the striae } \\
\text { or showing indistinct } \\
\text { lateral lines }\end{array}$ \\
\hline \multicolumn{5}{|c|}{ Male } \\
\hline Head shape & - & $\begin{array}{l}\text { Head weakly offset, } \\
\text { head cap low and } \\
\text { slightly narrower than } \\
\text { the postlabial region. } \\
\text { Postlabial incisures } \\
\text { absent }\end{array}$ & $\begin{array}{l}\text { Head slightly set off, } \\
\text { labial cap shallowly } \\
\text { rounded, one-fifth to } \\
\text { one-fourth as high as } \\
\text { postlabial region }\end{array}$ & $\begin{array}{l}\text { Head weakly offset, } \\
\text { head cap low and } \\
\text { slightly narrower than } \\
\text { the postlabial region. } \\
\text { Postlabial incisures } \\
\text { absent }\end{array}$ \\
\hline Stylet knobs & Knobs rounded & $\begin{array}{c}\text { Backwardly sloping } \\
\text { with rounded to pear } \\
\text { shaped knobs }\end{array}$ & $\begin{array}{c}\text { Knobs rounded to pear } \\
\text { shaped more or less } \\
\text { backwardly sloping }\end{array}$ & $\begin{array}{l}\text { Backwardly sloping } \\
\text { with rounded to pear } \\
\text { shaped knobs }\end{array}$ \\
\hline \multicolumn{5}{|c|}{ Second-stage juvenile } \\
\hline Stylet knobs & $\begin{array}{l}\text { Knobs backwardly } \\
\text { sloped }\end{array}$ & $\begin{array}{c}\text { Small rounded knobs, } \\
\text { slightly backwardly } \\
\text { sloping }\end{array}$ & $\begin{array}{c}\text { Knobs rounded and set } \\
\text { off from shaft }\end{array}$ & $\begin{array}{c}\text { Small rounded knobs, } \\
\text { backwardly sloping }\end{array}$ \\
\hline Tail shape & Short & $\begin{array}{l}\text { Conical with a broad } \\
\text { to finely pointed tip }\end{array}$ & $\begin{array}{c}\text { Conical, tapering to a } \\
\text { finely rounded almost } \\
\text { pointed terminus or } \\
\text { broader and rounded } \\
\text { at the tip }\end{array}$ & $\begin{array}{l}\text { Conical and tapers } \\
\text { to a broadly or finely } \\
\text { pointed tip }\end{array}$ \\
\hline $\begin{array}{l}\text { Hyaline tail } \\
\text { part }\end{array}$ & - & $\begin{array}{l}\text { Constrictions present } \\
\text { along hyaline part, } \\
\text { length short or long. } \\
\text { Anterior part clearly } \\
\text { delimitated } \\
\end{array}$ & $\begin{array}{c}\text { Cuticular constrictions } \\
\text { present along hyaline } \\
\text { tail terminus, variable } \\
\text { in length }\end{array}$ & $\begin{array}{l}\text { Constrictions present } \\
\text { along hyaline part, } \\
\text { anterior part clearly } \\
\text { delimitated }\end{array}$ \\
\hline
\end{tabular}

\section{Secretory-excretory pore}

S-E pore position measured from the anterior end showed quite some variations. Nevertheless, all measurements taken for both species fell within the range described for $M$. ulmi. This character in M. mali description was measured on the basis of the number of annuli counted from the anterior end to the one bearing the S-E pore. 


\section{Male}

\section{Head region}

Under light microscope, both species have the same head outline. This was already illustrated in the descriptions of the two species (Itoh et al. 1969; Palmisano and Ambrogioni 2000). The head cap in both species is low. The presence of lip annuli mentioned in M. ulmi was observed on some of the paratypes studied as well as in some of the additional specimens included later from "Mierenbos". The post-labial cephalic region slightly set off from the remainder of the body. SEM observation of the en face view of the lip region was not part of this study. Nevertheless, this will be discussed further on in this work based on previous study conducted by Yaegashi and Okamoto (1981) as well as the original description of M. ulmi.

\section{Stylet}

The stylet moderately slender. Conus with bluntly pointed tip. The shaft width the same along its entire length, although in some specimens it appeared to be broader close to the junction with the knobs. Individual knobs rounded to pear shaped. Knobs backwardly sloping in both species.

\section{Lateral field}

The lateral field marked by four incisures. In most of the specimens studied, the outer lines appeared areolated along most part of the body. No difference in the number of lateral incisures was observed along the body, except at the anterior part where it reduces to two and gradually fades out further anterior.

\section{Hemizonid position relative to $S$-E pore}

Although not considered to be of any diagnostic significance, this character remained fairly consistent in all specimens studied. The hemizonid always occurred anterior to the S-E pore, at slightly varying distances.

\section{Second-stage juveniles}

Examination of the second-stage juvenile characters was based on six $M$. mali type specimens and two of $M$. ulmi.

\section{Head region}

Head slightly set off from the rest of the body, with a low lip. Post-labial region lacking any annule.

\section{Stylet}

Stylet somewhat slender, with conus terminating in a fine tip, in both species. Stylet knobs small and rounded; slightly backwardly sloping.

\section{Hemizonid position relative to $S$-E pore}

Contrary to the condition in males, hemizonid always located behind the S-E pore in second-stage juveniles. However, the exact position is variable. 


\section{Tail}

Tail mostly straight, ranging from short to medium; with a fine to bluntly rounded tip. Hyaline tail terminus with varying length, anterior part distinctly delimitated.

\section{Morphometrics}

\section{Females}

Almost all our average measurements were within the range of those in the original descriptions (Table 4-6). In the case of M. ulmi, measured values of the female anterior part are based only on a single paratype specimen. Useful differential characters like the stylet length, stylet knob widths and stylet knob heights showed great similarities. From the perineal patterns, measurements of all the known important features also gave comparable values with those in the descriptions. Interphasmidial distance and the vulva slit were in most cases similar, rarely significantly different. In M. mali, these two measurements were almost identical. There was however, a slight difference in these two measurements from M. ulmi types (Table 4), probably because only two perineal patterns were studied.

\section{Males}

Three male paratypes of $M$. mali and two of $M$. ulmi were measured. Some of the studied characters were only visible enough for measurement on single specimens, and therefore for such characters absolute values were taken rather than their averages. The stylet knobs widths and heights were examples of characters for which measurements were not taken on either species (Table 5) due to the fact that they appeared slightly degenerated on all slides, and so may give false measurements. Nevertheless there were still some outstanding similarities in the stylet length, spicule length and DGO between the observed and the described values.

\section{Second-stage juveniles}

Similar to the observations made in the females and the males, the second-stage juvenile morphometrics was very comparable in many features between the two species studied. There was, however an unaccountable difference between stylet length as described for M. mali $(14 \mu \mathrm{m}(12-15 \mu \mathrm{m}))$ and that which was measured $(12.1 \pm 1.5 \mu \mathrm{m}$ $(10.9-13.8 \mu \mathrm{m}))$. Values of body width at anus level between the two descriptions were very similar. Some measurements taken from $M$. ulmi, likewise were quite similar to those in the original descriptions, particularly, the Demanian ratios a and c', while others such as stylet lengths showed slight differences (Table 6).

\section{Host test}

The ability of $M$. ulmi to reproduce on various plant species was examined under greenhouse conditions. Host statuses of the various plants used in the greenhouse test are presented in Table 7. M. ulmi population from "Mierenbos" used as inoculum was 
Table 4. Morphometrics of M. mali and M. ulmi females in comparison with the original descriptions. All measurements are in $\mu \mathrm{m}$ and in the form: mean \pm sd. (range).

\begin{tabular}{|c|c|c|c|c|}
\hline \multirow{2}{*}{$\begin{array}{c}\text { Species } \\
\text { Character }\end{array}$} & \multicolumn{2}{|c|}{ Meloidogyne mali } & \multicolumn{2}{|c|}{ Meloidogyne ulmi } \\
\hline & Described & Observed & Described & Observed \\
\hline $\mathrm{N}$ & 25 & 17 & 30 & $2^{*}$ \\
\hline Body length & $\begin{array}{c}847 \\
(684-1044)\end{array}$ & $\begin{array}{l}762 \pm 115 \\
(608-890)\end{array}$ & $\begin{array}{c}771 \pm 140 \\
(568-1043)\end{array}$ & - \\
\hline Body width & $\begin{array}{c}660 \\
(540-864)\end{array}$ & $\begin{array}{l}570 \pm 122 \\
(372-700)\end{array}$ & $\begin{array}{c}618 \pm 152 \\
(357-1007)\end{array}$ & - \\
\hline Neck length & $\begin{array}{c}166 \pm 43.7 \\
(90-252)\end{array}$ & $\begin{array}{l}165 \pm 62 \\
(60-265)\end{array}$ & $\begin{array}{l}165 \pm 67 \\
(58-382)\end{array}$ & 205 \\
\hline Neck diameter & - & $\begin{array}{c}100 \pm 34.3 \\
(48-160)\end{array}$ & - & 152 \\
\hline Stylet length & $\begin{array}{c}15 \\
(13-17)\end{array}$ & $\begin{array}{l}11.9 \pm 1.8 \\
(7.7-15.4)\end{array}$ & $\begin{array}{c}14.2 \pm 1.0 \\
(12.0-15.7)\end{array}$ & 13.4 \\
\hline Stylet knob height & - & $\begin{array}{c}1.6 \pm 0.3 \\
(1-2.2)\end{array}$ & $\begin{array}{l}1.8 \pm 0.6 \\
(1.1-3.9)\end{array}$ & 1.6 \\
\hline Stylet knob width & - & $\begin{array}{l}3.2 \pm 0.4 \\
(2.6-3.8)\end{array}$ & $\begin{array}{l}3.5 \pm 0.7 \\
(2.6-5.2)\end{array}$ & 3.2 \\
\hline DGO & $\begin{array}{c}5.5 \\
(4-7)\end{array}$ & $\begin{array}{l}4.3 \pm 1.5 \\
(2.2-6.7)\end{array}$ & $\begin{array}{l}4.6 \pm 0.8 \\
(3.3-6.5)\end{array}$ & 3.9 \\
\hline S-E pore & - & $\begin{array}{l}32.8 \pm 5.5 \\
(25-43.5)\end{array}$ & $\begin{array}{c}32.3 \pm 7.8 \\
(15.7-45.1)\end{array}$ & 36.5 \\
\hline Metacorpus & $\begin{array}{c}110 \\
(90-147)\end{array}$ & $\begin{array}{l}103 \pm 7.9 \\
(90-117)\end{array}$ & - & 92.8 \\
\hline Metacorpus length & $\begin{array}{c}39 \\
(32-44)\end{array}$ & $\begin{array}{c}40.4 \pm 4.5 \\
(32-50)\end{array}$ & $\begin{array}{c}42.6 \pm 6.5 \\
(32.7-58.8)\end{array}$ & 39.7 \\
\hline Metacorpus diameter & $\begin{array}{c}49 \\
(40-73)\end{array}$ & $\begin{array}{c}39.7 \pm 6.5 \\
(29-47)\end{array}$ & $\begin{array}{c}40.9 \pm 7.0 \\
(31.3-59.0)\end{array}$ & 36.5 \\
\hline Metacorpus valve length & $\begin{array}{c}12 \\
(11-13)\end{array}$ & $\begin{array}{c}13.0 \pm 1.1 \\
(11.5-15.4)\end{array}$ & $\begin{array}{c}12.4 \pm 1.0 \\
(11.1-14.4)\end{array}$ & 17.9 \\
\hline Metacorpus valve width & $\begin{array}{c}10 \\
(9-11)\end{array}$ & $\begin{array}{l}9.5 \pm 1.3 \\
(7-11.2)\end{array}$ & $\begin{array}{c}9.7 \pm 1.4 \\
(7.2-12.4)\end{array}$ & 10.2 \\
\hline Vulva - anus distance & $\begin{array}{l}17 \pm 1.8 \\
(14-22)\end{array}$ & $\begin{array}{c}19.1 \pm 2.6 \\
(12.8-22.4)\end{array}$ & $\begin{array}{c}19.0 \pm 1.9 \\
(15.0-22.2)\end{array}$ & $\begin{array}{c}19.2 \pm 0.8 \\
(18.8-19.8)\end{array}$ \\
\hline Interphasmidial distance & $\begin{array}{l}22 \pm 3.5 \\
(17-29)\end{array}$ & $\begin{array}{c}24.8 \pm 4.7 \\
(17.6-35.2)\end{array}$ & $\begin{array}{c}19.2 \pm 3.8 \\
(13.7-28.9)\end{array}$ & $\begin{array}{c}22.4 \pm 4.5 \\
(19.2-25.6)\end{array}$ \\
\hline Level of phasmids to vulva & $\begin{array}{l}25 \pm 2.4 \\
(19-31)\end{array}$ & $\begin{array}{l}27.4 \pm 2.8 \\
(24-33.9)\end{array}$ & $\begin{array}{c}25.1 \pm 4.2 \\
(15.7-39.2)\end{array}$ & $\begin{array}{c}27.6 \pm 0.9 \\
(26.9-28.2)\end{array}$ \\
\hline Level of phasmids to anus & - & $\begin{array}{c}8.1 \pm 2.5 \\
(5.1-12.8)\end{array}$ & $\begin{array}{c}6.9 \pm 2.2 \\
(2.6-15.7)\end{array}$ & $\begin{array}{l}8.7 \pm 1.3 \\
(7.7-9.6)\end{array}$ \\
\hline Vulva slit length & $\begin{array}{l}18 \pm 2.5 \\
(12-24)\end{array}$ & $\begin{array}{l}24.4 \pm 3.3 \\
(16-28.2)\end{array}$ & $\begin{array}{l}22.0 \pm 2.9 \\
(17-28.7)\end{array}$ & $\begin{array}{c}24.5 \pm 1.1 \\
(23.7-25.3)\end{array}$ \\
\hline
\end{tabular}

*Two perineal patterns and a single anterior part.

able to induce galls and reproduce on both Ulmus glabra and U. hollandica 'belgica'. The apple 'M9' also had galls which contained egg-laying females. Although galls were induced by M. ulmi on Brassica oleracea var. gemmifera, most of these galls contained 

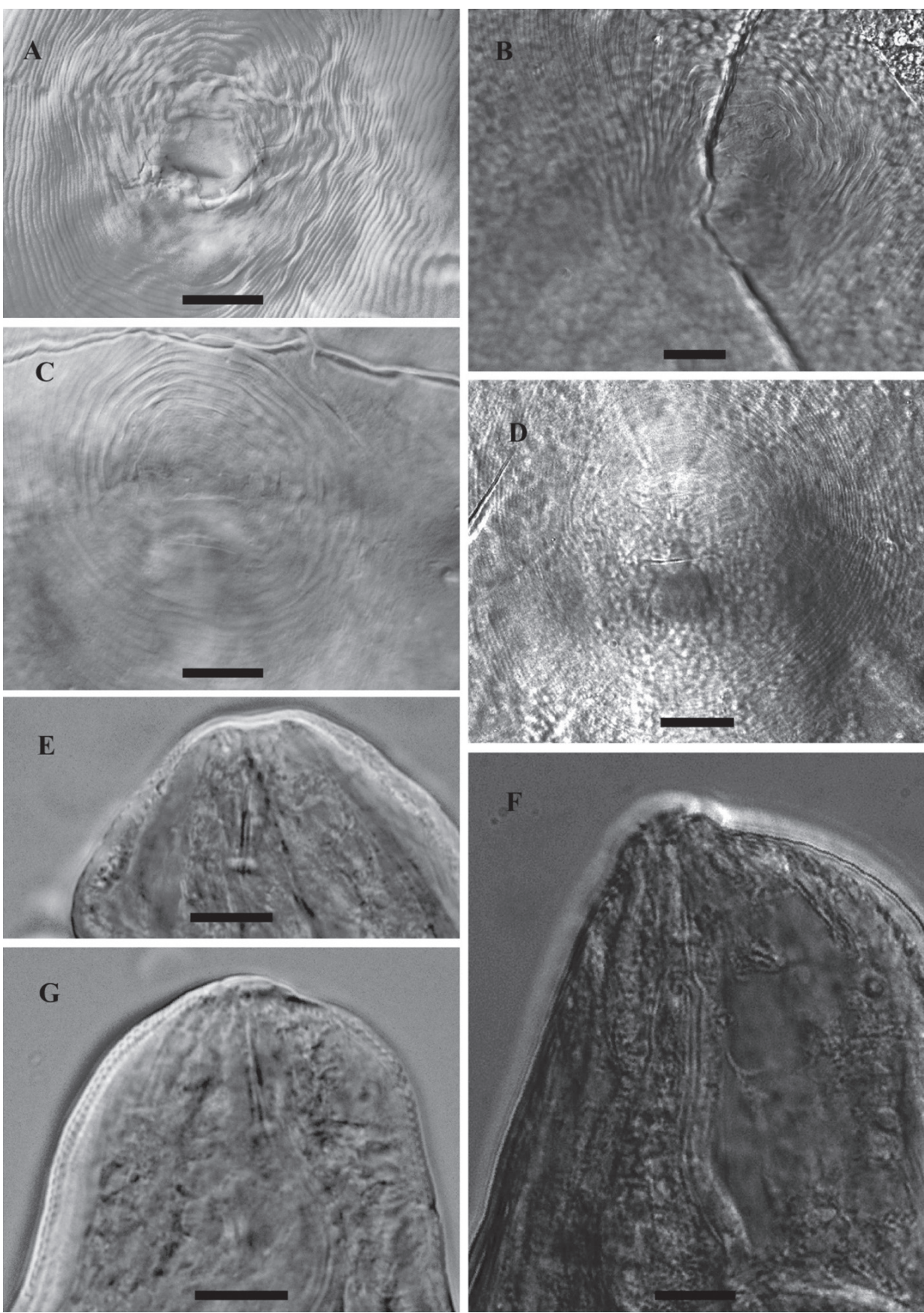

Figure I. LM photograph of perineal patterns and anterior parts of female Meloidogyne mali $(\mathbf{A}, \mathbf{C}, \mathbf{E}, \mathbf{G})$ and Meloidogyne ulmi (B, D, F), bar $=10 \mu \mathrm{m}$. 

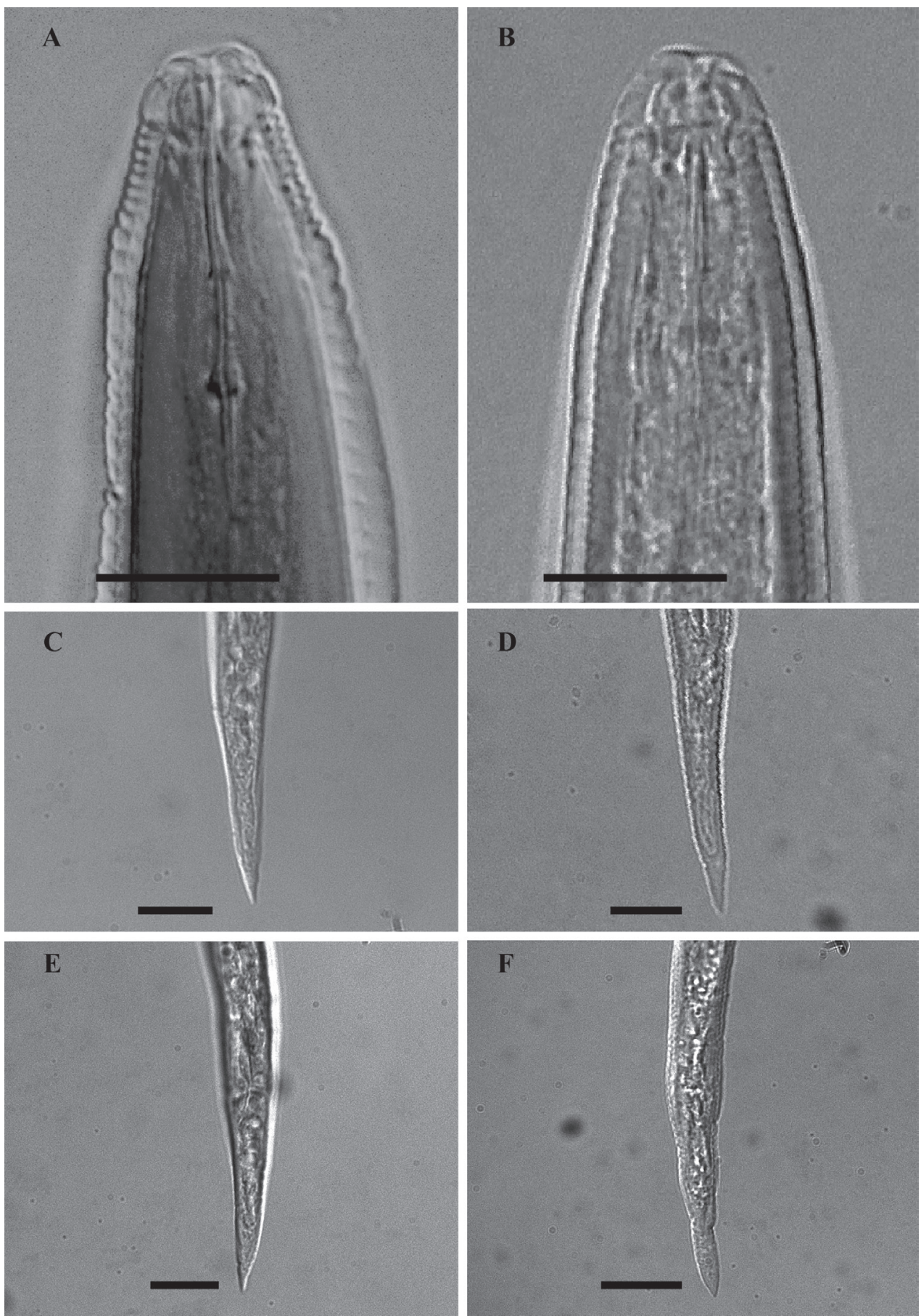

Figure 2. LM photographs of males anterior part and second- stage juvenile tails of Meloidogyne mali $(\mathbf{A}, \mathbf{C}, \mathbf{E})$ and Meloidogyne ulmi (B, D, F), bar $=10 \mu \mathrm{m}$. 
Table 5. Morphometrics of $M$. mali and M. ulmi males in comparison with the original descriptions. All measurements are in $\mu \mathrm{m}$ and in the form: mean \pm sd. (range).

\begin{tabular}{|c|c|c|c|c|}
\hline \multirow{2}{*}{$\begin{array}{c}\text { Species } \\
\text { Character }\end{array}$} & \multicolumn{2}{|c|}{ Meloidogyne mali } & \multicolumn{2}{|c|}{ Meloidogyne ulmi } \\
\hline & Described & Observed & Described & Observed \\
\hline $\mathrm{N}$ & 25 & 3 & 30 & 2 \\
\hline Body length & $\begin{array}{c}1447 \\
(1270-1630)\end{array}$ & $\begin{array}{c}1428 \pm 41.0 \\
(1380-1452)\end{array}$ & $\begin{array}{c}1462 \pm 190 \\
(1053-1776)\end{array}$ & $\begin{array}{c}1455 \pm 64 \\
(1410-15.0)\end{array}$ \\
\hline Body width & $\begin{array}{c}38 \\
(30-47) \\
\end{array}$ & $\begin{array}{c}34.8 \pm 9.6 \\
(28.0-41.8) \\
\end{array}$ & $\begin{array}{c}36.9 \pm 4.3 \\
(26.6-48.4) \\
\end{array}$ & $\begin{array}{c}40.5 \pm 0.7 \\
(40.0-41.0) \\
\end{array}$ \\
\hline Body width at stylet knobs & - & $\begin{array}{c}15.7 \pm 0.4 \\
(15.4-16.0) \\
\end{array}$ & $\begin{array}{c}16.7 \pm 1.3 \\
(14.5-19.4)\end{array}$ & $\begin{array}{c}17.6 \pm 1.1 \\
(16.8-18.4)\end{array}$ \\
\hline Body width at S.E pore & - & $\begin{array}{c}24.5 \pm 6.1 \\
(20.2-28.8)\end{array}$ & $\begin{array}{l}27.6 \pm 2.6 \\
(23.0-31.5\end{array}$ & $\begin{array}{c}28.4 \pm 0.6 \\
(28.0-28.8)\end{array}$ \\
\hline Stylet length & $\begin{array}{c}20 \\
18-22\end{array}$ & $\begin{array}{c}19.9 \pm 1.8 \\
(18.6-21.1)\end{array}$ & $\begin{array}{c}19.4 \pm 1.2 \\
(17.5-22.9)\end{array}$ & $\begin{array}{c}19.9 \pm 0.9 \\
(19.2-20.5)\end{array}$ \\
\hline Stylet knob height & - & - & $\begin{array}{l}2.4 \pm 0.1 \\
(2.0-3.0)\end{array}$ & - \\
\hline Stylet knob width & - & - & $\begin{array}{l}3.9 \pm 0.4 \\
(3.0-4.8)\end{array}$ & - \\
\hline DGO & $\begin{array}{c}8 \\
(6-13) \\
\end{array}$ & 9 & $\begin{array}{l}6.3 \pm 0.8 \\
(4.8-8.5)\end{array}$ & $\begin{array}{l}7.4 \pm 0.5 \\
(7.0-7.7)\end{array}$ \\
\hline S-E pore* & - & 135.2 & $\begin{array}{c}147 \pm 18.8 \\
(97-187) \\
\end{array}$ & $\begin{array}{l}139 \pm 7.1 \\
134-144\end{array}$ \\
\hline Metacorpus** & - & $\begin{array}{l}98 \pm 21.5 \\
(83-114)\end{array}$ & $\begin{array}{l}99 \pm 9.8 \\
(76-119) \\
\end{array}$ & $\begin{array}{l}83 \pm 12.7 \\
(134-144) \\
\end{array}$ \\
\hline Spicule & $\begin{array}{c}32 \\
(28-35) \\
\end{array}$ & $\begin{array}{l}28.1 \pm 10.3 \\
(20.8-35.3)\end{array}$ & $\begin{array}{c}33.8 \pm 1.9 \\
(30.0-37.5)\end{array}$ & 29.8 \\
\hline Gubernaculum & $\begin{array}{c}8.5 \\
(7-10)\end{array}$ & 10.1 & $\begin{array}{l}9.0 \pm 0.9 \\
(7.3-9.8)\end{array}$ & $\begin{array}{l}8.4 \pm 0.4 \\
(8.1-8.7)\end{array}$ \\
\hline Testis length & $\begin{array}{c}788 \\
(540-970)\end{array}$ & $\begin{array}{c}803 \pm 125.9 \\
(714-892)\end{array}$ & $\begin{array}{l}716 \pm 167 \\
(324-977)\end{array}$ & $\begin{array}{l}752 \pm 79 \\
(696-808)\end{array}$ \\
\hline $\mathrm{T}$ & $\begin{array}{c}55 \\
(34-65) \\
\end{array}$ & $\begin{array}{c}55.3 \pm 8.6 \\
(49.2-61.4) \\
\end{array}$ & $\begin{array}{l}48.7 \pm 9.7 \\
(27.9-71) \\
\end{array}$ & $\begin{array}{l}52 \pm 3.2 \\
(49-54)\end{array}$ \\
\hline
\end{tabular}

${ }^{*}$ Distance from anterior end to $S-E$ pore. ${ }^{* *}$ Distance from anterior end to valve plate of median bulb.

small non-gravid females whose development seemed to have ceased at some point. Therefore, it is herein not considered as a host. There were no galls on Rosa hybrida and the other cabbage species, B. pekinensis.

Additionally, samples collected during 2011 and 2012 revealed that M. ulmi is able to parasitize one or more species of Acer (Aceraceae), Impatiens (Balsaminaceae), Taraxacum (Compositae), Dryopteris (Dryopteridaceae), Fagus (Fagaceae), Quercus (Fagaceae), Geranium (Geraniaceae), Geum (Rosaceae), Rubus (Rosaceae), Sorbus (Rosaceae), Taxus (Taxaceae), Urtica (Urticaceae), as shown in Table 7. 
Table 6. Morphometrics of M. mali and M. ulmi second-stage juveniles in comparison with the original descriptions. All measurements are in $\mu \mathrm{m}$ and in the form: mean $\pm \mathrm{sd}$. (range).

\begin{tabular}{c|c|c|c|c}
\hline Species & \multicolumn{2}{|c|}{ Meloidogyne mali } & \multicolumn{2}{c}{ Meloidogyne ulmi } \\
\hline Character & Described & Observed & Described & Observed \\
\hline $\mathrm{N}$ & 25 & 5 & 30 & 3 \\
\hline \multirow{2}{*}{ Body length } & 418 & $420 \pm 21.7$ & $413 \pm 20.6$ & $384 \pm 9.5$ \\
& $(390-450)$ & $(390-446)$ & $(373-460)$ & $(374-394)$ \\
\hline \multirow{2}{*}{ Body width } & 14.5 & $14.0 \pm 1.1$ & $14.2 \pm 1.8$ & $12.7 \pm 3.8$ \\
& $(14-16)$ & $(12.2-15.2)$ & $(12.1-18.2)$ & $(8.6-16.9)$ \\
\hline \multirow{2}{*}{ Body diameter at anus } & 8.5 & $9.4 \pm 1.8$ & $8.4 \pm 1.0$ & $6.5 \pm 0.7$ \\
& $(7-9)$ & $(8.3-11.5)$ & $(7.3-10.9)$ & $(6.0-7.0)$ \\
\hline \multirow{2}{*}{ Stylet length } & 14 & $12.1 \pm 1.5$ & $10.0 \pm 0.8$ & $11.1 \pm 0.6$ \\
& $(12-15)$ & $(10.9-13.8)$ & $(8.5-11.1)$ & $10.6-11.5$ \\
\hline \multirow{2}{*}{ Tail length } & 31 & $30.2 \pm 4.3$ & $31.3 \pm 3.1$ & $24.2 \pm 0.8$ \\
& $(30-34)$ & $(24.3-33.9)$ & $(24.2-37.5)$ & $(23.4-25.0)$ \\
\hline \multirow{2}{*}{ Tail terminus length } & & $7.0 \pm 2.1$ & $8.2 \pm 1.8$ & $5.7 \pm 1.1$ \\
& - & $(5.1-9.8)$ & $(4.8-12.7)$ & $(4.5-6.7)$ \\
\hline \multirow{2}{*}{ Anus-primordium } & & $139 \pm 11.4$ & & $126 \pm 21.8$ \\
& - & $(125-152)$ & - & $(111-151)$ \\
\hline \multirow{2}{*}{ a } & 28.5 & $30.2 \pm 3.2$ & $29.5 \pm 3.4$ & $32.5 \pm 10.9$ \\
& $(27-31)$ & $(27.1-34.8)$ & $(22.3-35.5)$ & $(23.4-44.7)$ \\
\hline \multirow{2}{*}{ c } & 13.3 & $14.4 \pm 2.3$ & $13.3 \pm 1.2$ & $16.3 \pm 0.7$ \\
& $(12-15)$ & $(12.5-17.4)$ & $(11.5-16.6)$ & $(15.8-16.8)$ \\
\hline \multirow{2}{*}{ c' } & 3.7 & $3.3 \pm 0.7$ & $3.7 \pm 0.5$ & $3.7 \pm 0.5$ \\
& $(3-5)$ & $(2.5-3.9)$ & $(2.5-4.7)$ & $(3.3-4.1)$ \\
\hline
\end{tabular}

\section{Isozyme analysis}

Samples taken from the trial field "Mierenbos" all gave the same type of esterase isozyme pattern of weak single bands, corresponding to the VS1 type (Esbenshade and Triantaphyllou 1985). When analysed for $\mathrm{MDH}$, some individuals gave singlebanded patterns of the H1 type (Esbenshade and Triantaphyllou 1985), while others revealed a three-banded pattern, herein designated H3. Usually, the H1 type had two additional weaker bands at the same level as the upper two $\mathrm{H} 3$ bands. There was also an additional observation in the types of single bands some of the specimens produced (Fig. 3). These single bands were positioned at the same level as the upper $\mathrm{H} 3$ band, which herein are given the name H1a.

\section{Phylogenetic relationship between Meloidogyne mali and M. ulmi}

The obtained SSU rDNA and LSU rDNA sequence lengths for Meloidogyne ulmi were $781 \mathrm{bp}$ (including gaps) and 698bp (including gaps) respectively. In addition to our four SSU rDNA sequences of M. ulmi "Mierenbos" (KF895397, KF895398, KF895399 
Table 7. Plants species identified as host of $M$. ulmi from the green house experiments and field survey at "Mierenbos".

\begin{tabular}{|c|c|}
\hline Family & Plant species \\
\hline \multicolumn{2}{|l|}{ Greenhouse test } \\
\hline \multirow{2}{*}{ Ulmaceae } & Ulmus glabra Huds. \\
\hline & Ulmus hollandica 'belgica' \\
\hline Rosaceae & Malus pumila 'M9' \\
\hline Solanaceae & Solanum lycopersicum L. \\
\hline \multicolumn{2}{|l|}{ Field hosts } \\
\hline Sapindaceae & Acer pseudoplatanus L. \\
\hline Balsaminaceae & Impatiens parviflora $\mathrm{DC}$. \\
\hline Asteraceae & Taraxacum officinale F.H. Wigg. \\
\hline \multirow{2}{*}{ Dyopteridaceae } & Dryopteris filix-mas (L.) Schott \\
\hline & Dryopteris carthusiana (Vill.) H.P. Fuchs \\
\hline \multirow{2}{*}{ Fagaceae } & Fagus sylvatica $\mathrm{L}$. \\
\hline & Quercus robur $\mathrm{L}$. \\
\hline Geraniaceae & Geranium robertianum $\mathrm{L}$. \\
\hline \multirow{3}{*}{ Rosaceae } & Geum coccineum Lindl. \\
\hline & Rubus idaeus L. \\
\hline & Sorbus aucuparia L. \\
\hline Taxaceae & Taxus baccata L. \\
\hline Ulmaceae & Ulmus davidiana var. japonica Rehder \\
\hline Urticaceae & Urtica dioica L. \\
\hline
\end{tabular}

and KF895400), 69 accessions belonging to other species of Meloidogyne from GeneBank were included in the local alignment (781 aligned positions, including gaps). For LSU rDNA, we had only one sequence of M. ulmi "Mierenbos" (KF895396) due to poor data, resulting in lack of consensus sequence. Therefore the multiple sequence alignment included this sequence and 69 GeneBank accessions from other species of Meloidogyne. Pratylenchus vulnus Allen \& Jensen, 1951 was selected as outgroup for constructing gene trees using Bayesian inference from both SSU rDNA and LSU rDNA sequences. SSU rDNA-based phylogenetic analysis put all sequences of $M$. ulmi obtained together with those of $M$. mali and M. ulmi from GeneBank in one strongly supported polytomous branch. Despite the relatively short sequence length of SSU rDNA, the tree was able to resolve relationship between certain species in a way comparable with that of Holterman et al. (2009). LSU rDNA-based Bayesian analysis revealed higher resolution within the group containing our sequence and sequences of $M$. mali and $M$. ulmi from GeneBank. Our sequence of $M . u l m i$ was positioned in a branch that contained three other sequences of $M$. mali, forming a sister group to another branch composed also of two sequences of $M$. ulmi and one of M. mali. As would be expected, there was higher resolution in the overall topology of LSU rDNA-based tree than that of SSU rDNA. 

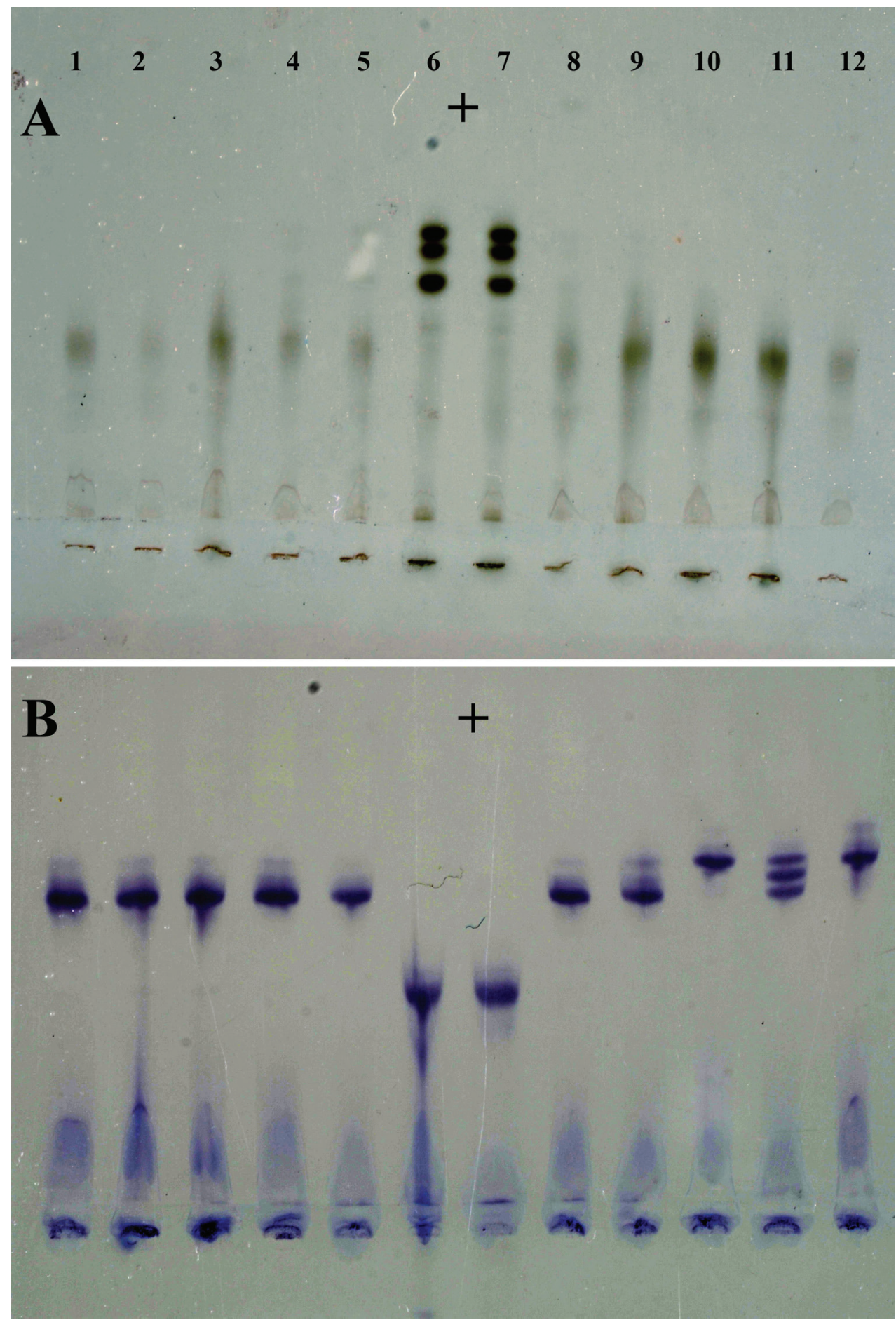

Figure 3. Isozyme phenotypes from ten individual females of Meloidogyne ulmi from "Mierenbos". A Esterase B Malate dehydrogenase. M. ulmi (1-5 and 8-12); M. javanica (6 and 7) as reference marker. 


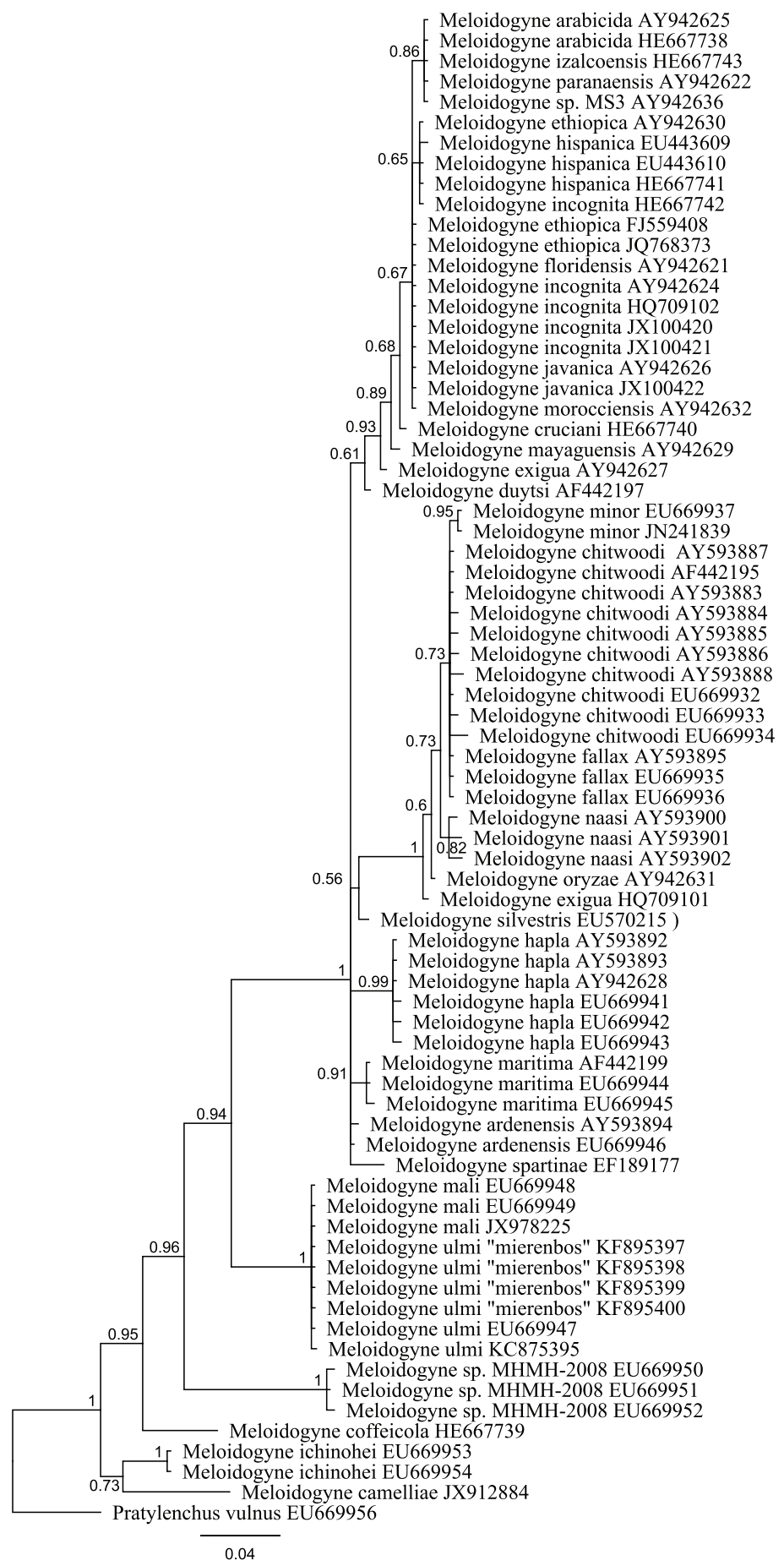

Figure 4. Bayesian tree inferred from part of $18 \mathrm{~S}$ rRNA using TYMef + I model. Sequences were aligned with MAFFT alignment. Numbers near the nodes indicate posterior probabilities. NCBI accession numbers are listed with the species names. 


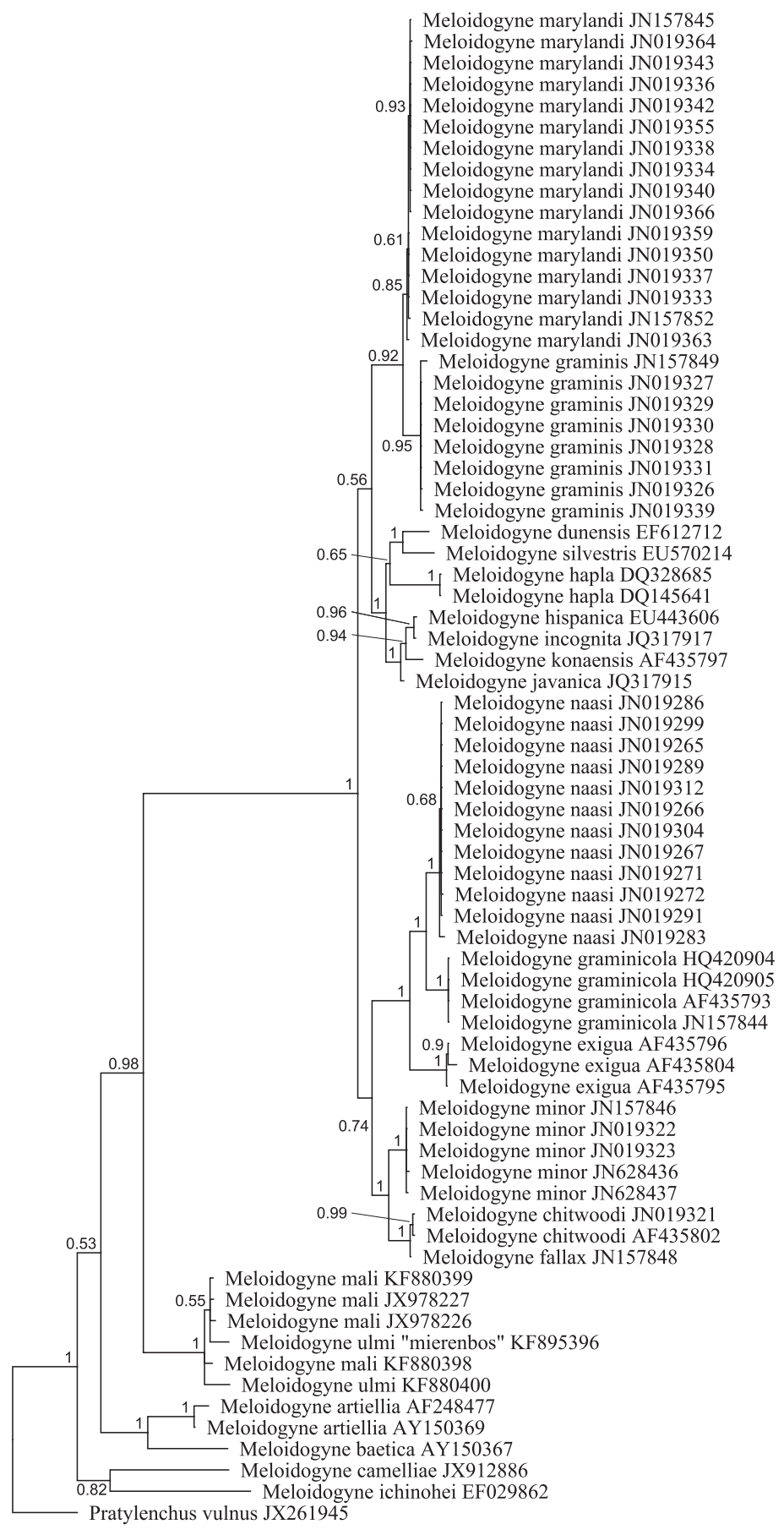

0.2

Figure 5. Bayesian tree inferred from part of D2 D3 of $28 \mathrm{~S}$ rRNA using TYM + G model. Sequences were aligned with MAFFT alignment. Numbers near the nodes indicate posterior probabilities. NCBI accession numbers are listed with the species names. 
The sequence identity between the closest sequences of $M$. mali and M. ulmi was 98.8 $\%$ with one gap. Interestingly, the same percentage was obtained between two sequences of Meloidogyne mali from GeneBank (JX978226 and JX978227).

\section{Discussion}

Type specimens representing holotypes and paratypes of the two Meloidogyne species were analysed in order to demonstrate the morphological similarities that existed between them. Most of the slides we received were in good conditions except for some few individuals that showed some signs of deterioration, either due to long period of storage or poor conditions at the time they were prepared. Nevertheless, the general states of the important characters were still maintained.

On the morphology, an important character like the occurrence of double lateral lines mentioned in the description and by Jepson (1987) was not observed in all specimens. In fact this area was marked by breaks in the striae on some of the specimens studied. Morphometric values of some characters for the two species fell within the range of values reported in the original description of M. mali (Itoh et al. 1969), for example position of DGO in females, as well as in males, vulva-anus distance, level of phasmids to vulva, vulva slit length, male stylet length, testis length, spicule length gubernaculum length, J2 body length, and J2 c' values (Tables 4-6). For some characters, however, morphometric values recorded agreed more with those reported for M. ulmi. For example, the stylet length measured in females and J2s was significantly lower than the values given for $M$. mali, but comparable with that of $M$. ulmi. A possible explanation might be the fact that stylet in juveniles and sometimes in females appear less visible, causing the anterior end to be mistaken for the tip of the conus. This leads to misleadingly higher values for the stylet length.

Already in the original description of M. ulmi, only a few differences could be found to separate it from M. mali. And in some cases, the differences emanated from some apparent mistakes in the original description of $M$. mali. An example is the use of male tail length of the two species to draw differences. Tail length in males of $M$. mali was given as ranging between 28 and $44 \mu \mathrm{m}$, making it extremely longer than that of M. ulmi 10.9 $\mu \mathrm{m}$. However, it is important to mention that tail length values as long as the range of between 28 and $44 \mu \mathrm{m}$ never exists among males of species of the genus Meloidogyne.

The DGO position in males with reference to the stylet knobs according to Jepson (1987) bears some broad interspecific variation, making it very useful for species discrimination. M. mali is by far the species with the most farther DGO position (6-13 $\mu \mathrm{m})$ within the genus Meloidogyne. The observation of similar values for both species studied here therefore separates the two from all other species that have relatively shorter DGO position. Additional M. ulmi specimens studied also gave DGO position values averaging $8 \mu \mathrm{m}$ (data not shown).

Eisenback and Hirschmann (1981) highlighted the significance of SEM studies of male head shapes in Meloidogyne taxonomy, outlining the role SEM has played 
in raising the value of males for use in comparison of species. Head and stylet shape morphologies of males and juveniles are the most useful supplemental taxonomic characters that SEM studies have given new insights into (Eisenback and Hirschmann $1979 ; 1981)$. It is not surprising that a number of variability in these characters were outlined to separate $M$. ulmi from $M$. mali by Palmisano and Ambriogioni (2000). It was mentioned (p. 288) that "under SEM lateral lips absent or vestigial (in M. mali lateral lips apparent)". Interestingly, this contradicted the comparison made by Toida and Yaegashi (1984) when they attempted to point out the differentiating characters between $M$. suginamiensis and $M$. mali. In their comparison, the en face view of the lip region of $M$. mali was mentioned as having no or obscure lateral lips to separate it from M. suginamiensis in which lateral lips were described as clear. One would not expect such contradicting accounts especially with the possibility that both works referred to the same publication (Okamoto et al. 1983). Referring to a separate work (Yeagashi and Okamoto 1981), the account given by Toida and Yaegashi (1984) seems to us more probable, the first reason being that they published the same work which is being referred to. Therefore they understand the details of their results more. And the second reason is that our observations of SEM images of (Yeagashi and Okamoto 1981) agree more with the account that lateral lips were vestigial and not apparent in $M$. mali.

Both apple and elm trees supported $M$. ulmi reproduction. This does not only provide an additional support for the synonymization of $M$. ulmi with $M$. mali, but represents the first and only test involving the former on an apple plant. In principle, however, the first actual report was the description of $M$. mali on apple in Japan (Itoh et al. 1969). Contrary to the finding in the original description, the status of white clover as host to $M$. mali could not be confirmed with $M$. ulmi. Again, although representatives of the family Rosaceae form the larger part of the plants $M$. mali parasitizes (Itoh et al. 1969; Toida 1979), rose (Rosa hybrida) could not support the reproduction of $M$. ulmi. This contradicts earlier finding, Itoh et al. 1969, who identified rose as host. $M$. ulmi was also able to induce galls on Prunus yodoensis grown in the field, confirming the earlier report of the latter's status as a host for $M$. mali by Toida (1979). Results of the sampling have also revealed new natural hosts for Meloidogyne ulmi like Acer pseudoplatanus L., Fagus sylvatica L., Quercus robur L., Rubus idaeus L., Sorbus aucuparia L., Taxus baccata L., Dryopteris filix-mas (L.) Schott, Dryopteris carthusiana (Vill.) Fuchs, Geranium robertianum L., Urtica dioica Rehder., Impatiens parviflora DC., Taraxacum officinale F.H. Wigg., and Geum coccineum Lindl. The most relevant evidence deduced from this host plant test is the ability of $M . u l m i$ to reproduce on apple.

It is interesting to mention that the observed variability of the MDH isozyme phenotypes among the different specimens was similar to the findings of Sakai and Mizukubo (2009) when they studied two populations of $M$. mali from Hokkaida on apple and Saitama on cherry in Japan. The populations from Hokkaida gave phenotypes with single $\mathrm{MDH}$ bands whereas those from Saitama on cherry produced variable patterns with single and triple bands. PCR-RFLP of D2/D3 expansion segment of $28 \mathrm{~S}$ rDNA and mtDNA intergenic region with $A l u$ I was able to confirm that population from Saitama were all identical, despite their expression of variable $\mathrm{MDH}$ isozyme pheno- 
types. Similar observations of intraspecific phenotype variations were made by Dalmasso and Bergé (1978) among a certain $M$. arenaria population where there were three $\mathrm{MDH}$ bands instead of two. Such type of variable isozyme patterns were also observed within one population of the sexually reproducing species $M$. microtyla Mulvey, Townshend \& Potter, 1975 (Karssen unpublished). This indicates that M. mali could also be a sexually reproducing species or a meiotic parthenogenetic one, a claim which is further supported by the frequency at which males are encountered in galled root samples-at least one male per female in a gall. Meanwhile, the esterase phenotypes were rather stable across all studied specimens and were characterised by weak indistinct single bands.

Trimming the SSU and LSU datasets to high quality sequence data may have caused a loss in phylogenetic signal. For SSU rDNA, over half of the target sequence length was trimmed out because of the poor quality of the dataset obtained. Although not ideal for reconstruction of phylogeny, it was still sufficient to resolve the taxa on a species level. Moreover, it has to be emphasized that the purpose here is not to reconstruct any formal phylogeny of Meloidogyne, a subject which is well covered already in previous studies (Tandingan De Ley et al. 2002; Holterman et al. 2009), but only to demonstrate that M. mali and M. ulmi are highly similar at the molecular level and belong to the same clade. A recent phylogenetic analyses involving these two species has already pointed to the fact that the two can not be separated based on their SSU rDNA sequences (Rybarczyk-Mydłowska et al. in press). The SSU rDNA sequence once again gave resolution till the species level, confirming previous proposition that SSU rDNA sequence signatures can be defined at species level for a wide range of parasitic and non-parasitic nematodes (Holterman et al. 2006). As was expected, LSU rDNA-based analysis gave even higher resolution and more clearly defined the relationship between M. mali and M. ulmi. On the SSU rDNA based tree, it is unquestionable that our sequence of $M$. ulmi with all the other sequences of M. mali and M. ulmi are the same (Fig. 4). The clustering of our sequence of LSU rDNA for M. ulmi with those for M. mali may be an indication that the branching could only be due to intraspecific sequence variation.

\section{Conclusion}

In conclusion, the evidence from morphological and morphometrical studies of holoand paratype materials of Meloidogyne mali and M. ulmi as well as host plant studies, isozyme analysis and DNA analysis all confirm the status of $M$. ulmi as a junior synonym of $M$. mali.

\section{Notes on the life cycle and biology of Meloidogyne mali on Ulmus spp.}

The life cycle of Meloidogyne mali is in many respects typical of the genus. Meloidogyne mali requires 18-22 weeks to complete one full generation on apple and does so only once in a year (Inagaki 1978). The study also reported that adult males and females 
Table 8. A compilation of all known host plants of Meloidogyne mali to date.

\begin{tabular}{|c|c|c|}
\hline Family & Plant species & Reference \\
\hline \multirow{10}{*}{ Rosaceae } & Malus pumila Mill. & Itoh et al. 1969 \\
\hline & Malus prunifolia Borkh. & Itoh et al. 1969 \\
\hline & Malus sieboldii Rehd. & Itoh et al. 1969 \\
\hline & Malus pumila "M9" & Current work \\
\hline & Prunus yedoensis Matsum & Itoh et al. 1969 \\
\hline & Rosa hybrida Hort. & Itoh et al. 1969 \\
\hline & Geum coccineum Lindl. & Current work \\
\hline & Vitis vinifera $\mathrm{L}$. & Itoh et al. 1969 \\
\hline & Rubus idaeus L. & Current work \\
\hline & Sorbus aucuparia L. & Current work \\
\hline \multirow{5}{*}{ Moraceae } & Morus bombycis Koidz. & Itoh et al. 1969 \\
\hline & Ficus carica L. & Toida 1979 \\
\hline & Maclura tricuspidata (Carriere) Bureau & Toida 1979 \\
\hline & Broussonetia papyrifera (L.) Vent & Toida 1979 \\
\hline & Broussonetia kazinoki Seibold. & Toida 1979 \\
\hline \multirow{3}{*}{ Fagaceae } & Castanea crenata Seib. Et Zucc & Itoh et al. 1969 \\
\hline & Fagus sylvatica L. & Current work \\
\hline & Quercus robur $\mathrm{L}$. & Current work \\
\hline \multirow{4}{*}{ Ulmaceae } & Ulmus davidiana var. japonica & Toida 1979 \\
\hline & Ulmus chenmoui W.C. Cheng & Palmisano and Ambrogioni 2000 \\
\hline & Ulmus glabra Hud. & Palmisano and Ambrogioni 2000 \\
\hline & Ulmus $\times$ hollandica "belgica" & Current work \\
\hline \multirow{3}{*}{ Sapindaceae } & Acer palmatum Thunb. & Itoh et al. 1969 \\
\hline & Acer pseudoplatanus L. & Current work \\
\hline & Trifolium repens $\mathrm{L}$. & Itoh et al. 1969 \\
\hline Taxaceae & Taxus baccata L. & Current work \\
\hline Fabaceae & Impatiens parviflora DC. & Current work \\
\hline \multirow{3}{*}{ Solanaceae } & Solanum lycopersicum L. & Toida 1979 \\
\hline & Solanum melongena L. & Toida 1979 \\
\hline & Capsicum annuum $\mathrm{L}$. & Toida 1979 \\
\hline \multirow{3}{*}{ Cucurbitaceae } & Cucumis sativus $\mathrm{L}$. & Toida 1979 \\
\hline & Cucurbita spp. & Toida 1979 \\
\hline & Citrillus vulgaris Schrad. Ex Eckl. \& Zeyh. & Toida 1979 \\
\hline \multirow{3}{*}{ Cruciferae } & Brassica pekinensis Rupy. & Toida 1979 \\
\hline & Brassica oleracea var. capitata L. & Toida 1979 \\
\hline & Brassica napus var. oleifera L. & Toida 1979 \\
\hline \multirow{2}{*}{ Compositae } & Arcutium lappa L. & Toida 1979 \\
\hline & Taraxacum officinale F.H. Wigg. & Current work \\
\hline Umbelliferae & Daucus carota var. sativa $\mathrm{L}$. & Toida 1979 \\
\hline Leguminaceae & Glycine $\max (\mathrm{L}$.$) Merr.$ & Toida 1979 \\
\hline Urticaceae & Urtica dioica $\mathrm{L}$. & Current work \\
\hline \multirow{2}{*}{ Dryopteridaceae } & Dryopteris filix-mas (L.) Schott & Current work \\
\hline & Dryopteris carthusiana (Vill.) H.P. Fuchs & Current work \\
\hline Geraniaceae & Geranium robertianum $\mathrm{L}$. & Current work \\
\hline
\end{tabular}




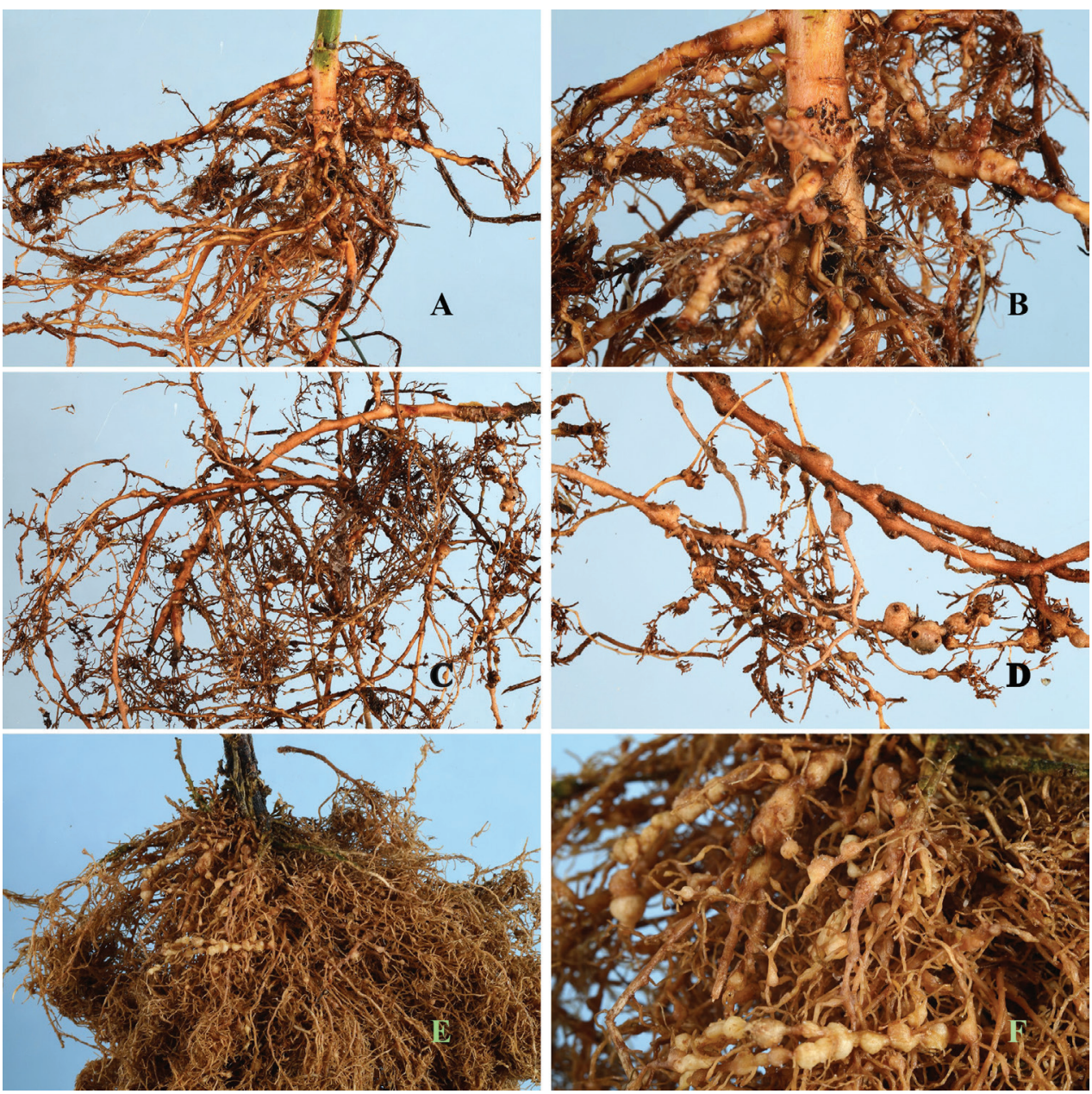

Figure 6. Root gall symptoms of Meloidogyne mali infection on (A, B) Malus pumila "M9" (C, D) Ulmus davidiana var. japonica and (E, F) Solanum lycopersicum.

first were observed after twelve weeks and continued to increase till the twentieth, when egg masses began to appear. There was also some reports on the distribution of M. mali in the field, both vertically and horizontally. However, nothing is known so far about its survival on apple or any other plant during frost conditions of winter. Regarding this, a very interesting observation was made during early spring of 2013 at the trial field "Mierenbos". Egg-laying females were already found in most galls that were examined, a rare phenomenon known to occur only in $M$. ardenensis (Stephan and Trudgill 1982). The only plausible explanation to why egg-laying females can be observed so early in the year is that, like reported for $M$. ardenensis, the nematodes overwintered in the roots. Additional observations need to be made to find out exactly what stage in the development overwinters in the root. 


\section{Host plants and distribution of $M$. mali in Europe}

Meloidogyne mali induces a similar type of galls as do $M$. arenaria on tomatoes, a type of gall commonly referred to as bead-like galls (Fig. 6). Concerning the current distribution of the nematode in Europe, no study has yet been done to investigate this. However, it would be rational to speculate that $M$. mali may be found in all the ten European countries to which rooted seedlings were sent after the breeding programme. These countries include Belgium, England, France, Ireland, Italy, Spain, Denmark, Germany, Slovakia and Romania (Heybroek 1993). Elsewhere in Asia, it has also been found in Acer palmatum trees from Japan that were intercepted in China (Gu unpublished). Sequence data from these were also included in the analysis.

\section{Acknowledgement}

The authors are grateful to the following people for their help with providing type slides for study: Dr. Z.A. Handoo, Shigeyuki Sekimoto and Dr. Hiromichi Sakai. They also wish to thank Takayuki Mizukubo for providing root sample from the type apple tree, and to Tiziana Irdani and Beatrice Carletti for Elm root materials from the type tree. Evelyn van Heese for helping with slides preparation and electrophoresis, Anne-Sophie van Bruggen and Johan van Woggelum for help with field sampling and host plant tests. They are also grateful to Dr. M. Heybroek, formally of the Dorschkamp Research Institute for Forestry \& Landscape Planning, for providing essential information about the Ulmus breeding programme. Very special thanks also to Eveline Metz-Verschure and Dr. Marcel Westenberg for their help with molecular analysis.

\section{References}

Blok VC, Powers TO (2009) Biochemical and molecular identification. In: Perry R, Moens M, Starr J (Eds) Root-knot Nematodes. CABI Publishing, Wallingford, UK, 98-118.

Brinkman H (1980) Wortelknobbelaaltjes (Meloidogyninae). Verslagen en Mededelingen Plantenziektenkundige Dienst Wageningen (Jaarboek 1979) 56: 47.

Carneiro RMDG, Almeida MRA, Queneherve P (2000) Enzyme phenotypes of Meloidogyne spp. populations. Nematology 2: 645-654. doi: 10.1163/156854100509510

Dalmasso A, Bergé J (1978) Molecular polymorphism and phylogenetic relationship in some Meloidogyne spp.: Application to the taxonomy of Meloidogyne. Journal of Nematology 10: 323-332.

Darriba D, Taboada GL, Doallo R, Posada D (2012) JModel Test 2: more models, new heuristics and parallel computing. Nature Methods 9: 772. doi: 10.1038/nmeth.2109

Eisenback JD, Hirschmann H (1981) Identification of Meloidogyne species on the basis of head shape and stylet morphology of the male. Journal of Nematology 13: 513-521. 
Eisenback JD, Hirschmann H (1979) Morphological comparison of second-stage juveniles of several Meloidogyne species (root-knot nematodes) by scanning electron microscopy. Scanning Electron microscopy 3: 223-229.

Esbenshade P, Triantaphyllou A (1985) Use of enzyme phenotypes for identification of Meloidogyne species. Journal of Nematology 17: 6-20.

Heybroek HM (1983) Resistant elms for Europe. In: Burdekin DA (Ed) Research on Dutch elm disease in Europe. Forestry Commission Bulletin 60, HMSO, UK, 108-113.

Heybroek HM (1993) The Dutch elm breeding program: In: Sticklen MB, Sherald JL (Eds) Dutch elm disease research: Cellular and molecular approaches. Springer-Verlag, NY, 1625. doi: 10.1007/978-1-4615-6872-8_3

Heybroek HM, Goudzwaard L, Kaljee H (2009) Iep of olm, karakterboom van de Lage Landen. KNNV Uitgeverij, 272 pp.

Holterman M, Karssen G, van den Elsen S, van Megen H, Bakker J, Helder J (2009) Small subunit rDNA-based phylogeny of the Tylenchida sheds light on relationships among some high-impact plant-parasitic nematodes and the evolution of plant feeding. Phytopathology 99: 227-235. doi: 10.1094/PHYTO-99-3-0227

Holterman M, Rybarczyk K, van den Elsen S, van Megen H, Mooyman P, Santiago RP, Bongers T, Bakker J, Helder J (2008) A ribosomal DNA-based framework for the detection and quantification of stress-sensitive nematode families in terrestrial habitats. Molecular Ecology Resources 8: 23-34. doi: 10.1111/j.1471-8286.2007.01963.x

Holterman M, van der Wurff A, van Den Elsen S, van Megen H, Bongers T, Holovachov O, Bakker J, Helder J (2006) Phylum wide analysis of SSU rDNA reveals deep phylogenetic relationships among nematodes and accelerated evolution toward crown clades. Molecular Biology and Evolution 23: 1792-1800. doi: 10.1093/molbev/msl044

Huelsenback JP, Ronquist F (2001) MR-BAYES: Bayesian inference of phylogeny. Bioinformatics 17: 754-755. doi: 10.1093/bioinformatics/17.8.754

Inagaki H (1978) Apple root-knot nematode Meloidogyne mali, its taxonomy, ecology, damage and control. Second Asian Regional Conference on root-knot nematodes. Thailand Kasetsart Journal 12: 25-30.

Itoh Y, Ohshima Y, Ichinohe M (1969) A root-knot nematode, Meloidogyne mali n. sp. on appletree from Japan (Tylenchida: Heteroderidae). Applied Entomology and Zoology 4: 194-202.

Jepson SB (1987) Identification of Root-knot Nematodes (Meloidogyne species). Commonwealth Agricultural Bureaux, Farnham Royal, UK, 265 pp.

Karssen G, Wesemael W, Moens M (2013) Root-knot nematodes. In: Perry RN, Moens M (Eds) Plant Nematology. $2^{\text {nd }}$ edition, CAB International, Wallingford, UK, 73-108.

Karssen G (2002) The plant-parasitic nematode genus Meloidogyne Göldi, 1892 (Tylenchida) in Europe. Brill Academic Publishers, Leiden, The Netherlands, 161 pp.

Karssen G (2009) Een nieuwe iepenwortelparasiet. In: Heybroek HM, Goudzwaard L, Kaljee H (Eds) Iep of Olm: Karakterboom van de Lage Landen. KNNV Uitgeverij, Zeist, 132.

Karssen G, van Keulen I, van Hoenselaar T, van Heese E (2008) Meloidogyne ulmi: een nieuwe iepen parasiet in Nederland? Boomzorg 1: 62-63. 
Karssen G, van Hoenselaar T, Verkeberk-Bakker B, Janssen R (1995) Species identification of cyst and root-knot nematodes from potato by electrophoresis of individual females. Electrophoresis 16: 105-109. doi: 10.1002/elps.1150160119

Katoh K, Misawa K, Kuma K, Miyata T (2002) MAFFT: a novel method for rapid multiple sequence alignment based on fast Fourier transform. Nucleic Acids Resources 30: 3059-3066. doi: $10.1093 / \mathrm{nar} / \mathrm{gkf} 436$

Okamoto K, Yaegashi T, Toida Y (1983) Morphological differences among some populations of Meloidogyne mali from apple and mulberry. Japanese Journal of Nematology 12: 26-32.

Oostenbrink M (1961) Enige bijzondere aaltjesaantastingen in 1960. Tijdschrift over Plantenziekten 67: 57-58.

Palmisano A, Ambrogioni L (2000) Meloidogyne ulmi sp. n., a root-knot nematode from elm. Nematologia Mediterranea 28: 279-293. http://journals.fcla.edu/nemamedi/article/ view/63531

Rybarczyk-Mydłowska K, van Megen H, van den Elsen S, Mooyman P, Karssen G, Bakker J, Helder J (in press) Both SSU rDNA and RNA polymerase II data recognize that root knot nematodes arose from migratory Pratylenchidae, but probably not from one of the economically high-impact lesion nematodes. Nematology, 15.

Sakai H, Mizukubo T (2009) Root-knot nematodes parasitizing the Japanese flowering cherry trees. Abstract of papers presented at the 17th meeting of the Japanese Nematological Society, Kumamoto, Japan, September 3-5, 2009. Japanese Journal of Nematology 39: 74.

Sambrook J, Fritsch EF, Maniatis T (1989) Molecular Cloning: A Laboratory Manual. Cold Spring Harbor Laboratory Press, Cold Spring Harbor, NY, 2344 pp.

Sasser J (1977) Worldwide dissemination and importance of the root-knot nematodes, Meloidogyne spp. Journal of Nematology 9: 26-29.

Sasser JN, Carter CC (1982) Root-knot nematodes (Meloidogyne spp.): Identification, morphological and physiological variation, host range, ecology, and control. In: Riggs RD (Ed) Nematology in the southern region of the United States. Southern Cooperative Series Bulletin 276, Arkansas Agricultural Experimental Station, Fayetteville, Ark, 21-32.

Stephan ZA, Trudgill DL (1982) Population fluctuation, life cycle of root-knot nematode, $M e$ loidogyne ardenensis in Cupar, Scotland, and the effect of temperature on its development. Revue de Nématologie 5: 281-284.

Tandingan De Ley I, De Ley P, Vierstraete A, Karssen G, Moens M, Vanfleteren J (2002) Phylogenetic analyses of Meloidogyne small subunit rDNA. Journal of Nematology 34: 319-327.

Toida Y, Yaegashi T (1984) Description of Meloidogyne suginamiensis n. sp. (Nematoda: Meloidoygnidae) from Mulberry in Japan. Japanese Journal of Nematology 12: 49-57.

Toida Y (1979) Host plants and morphology of the 2nd-stage larvae of Meloidogyne mali from mulberry. Japanese Journal of Nematology 9: 20-24.

Triantaphyllou AC (1979) Cytogenetics. In: Lamberti F, Taylor CE (Eds) Root-knot nematodes (Meloidogyne species): Systematics, Biology and Control. Academic Press, New York, 85-114.

Yaegashi T, Okamoto K (1981) Observations of six Meloidogyne species by scanning electron microscope 2. En face views of males. Japanese Journal of Nematology 10: 43-51. 
